\title{
CORRECTION OF MEAN VALUES OF RE-ESTABLISHED CYCLES WITH RESPECT TO THE CERTAIN PART OF WOLF NUMBER SERIES (VERSION V.1)
}

\author{
Shibaev I.G. \\ IZMIRAN, Troitsk, Russia
}

\section{КОРРЕКЦИЯ СРЕДНИХ ЗНАЧЕНИЙ ВОССТАНОВЛЕННЫХ ЦИКЛОВ ПО ХАРАКТЕРИСТИКАМ ДОСТОВЕРНОЙ ЧАСТИ РЯДА ЧИСЕЛ ВОЛЬФА ВЕРСИИ V.1}

Шибаев И.Г. ИЗМИРАН, Трочик, Россия

Работа опирается на цюрихский ряд среднемесячных чисел Вольфа $W$ (W=Wrest U Wtool), который включает восстановленный ряд Wrest (c 1749 г. по 1849 г.) и ряд достоверных данных Wtool (регулярные инструментальные наблюдения с 1849 2. по настоящее время). Многие исследователи используют ряд чисел Вольфа (или опирающуиеся на него показания) с учетом восстановленных данных. Но при объединении отрывочных данных с различными плотностью наблюдений, амплитудным разрешением и масштабированием исказятся, естественно, локальные характеристики регистрируемого прочесса и взаимосвязь временных фрагментов разного масштаба. Всё это проявилось при формировании восстановленного ряда Wrest [1, Fig.2], но на это обращают мало внимания, хотя влияние этих факторов не оценивалось.

Другие авторы, считая эти данные ненадежныли, опираются только на достоверный ряд Wtool. При этом «повисают» понятия (структуры) сформированные с опорой хотя бы на часть восстановленных данных. Цикл Гляйсберга [2] - яркий пример тому, т. к. понятие «цикл Гляйсберга» возникло из анализа небольшого объема данньхх,

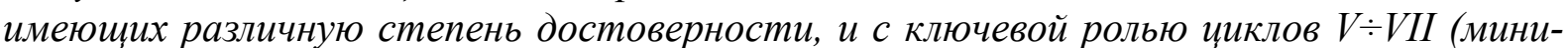
мум Дальтона) из восстановленного ряда. Отмеченный в работе [3] рост периода иикла Гляйсберга с увеличением доли достоверных данных хорошо это иллюстрирует.

В этой работе представлень варианты групповой коррекиии средних значений циклов $I \div I X$. Так как при сопоставлении протяженных фрагментов локальные невязки данных играют меньшую роль, то опираясь на интегральные оченки этих фрагментов (без детализачии их «сложной» истории формирования) мы получаем более взвешенные интервальные оценки. Параметры интервалов (групп ичиклов) достоверного ряда служат основой коррекиии. Приведенный сиенарий связывает согласование параметров восстановленного ряда с коррекцией минимума Дальтона, что должно отразиться в характеристиках ичикла Гляйсберга.

DOI: 10.31725/0552-5829-2021-313-316

\section{Introduction}

The paper considers the Zurich series of monthly averaged sunspot numbers $\mathrm{W}$ ( $\mathrm{W}=$ Wrest $\mathrm{U}$ Wtool), which includes the restored Wrest series (from 1749 to 1849 ) and Wtool, a series of reliable Wolf numbers (regular instrumental observations from 1849 to the present). Many researchers use a series of Wolf 
numbers (or readings based on it) taking into account the recovered data. When combining fragmentary data with different density of observations, amplitude resolution and scaling, the local characteristics of the recorded process and the consistency of time fragments of different scales (for example, the structure of the cycles and their relationship) are distorted.

All this manifested itself during the formation of the restored Wrest series [1, Fig.2], but little attention is paid to this, although the influence of these factors has not been evaluated.

Other authors, considering these data unreliable, rely only on the reliable Wtool series. At the same time, concepts (structures) "hang" generated based on at least part of the recovered data. The Gleisberg cycle [2] is a vivid example of this, since the concept of the "Gleisberg cycle" arose from the analysis of a small amount of data with varying degrees of reliability, and with the key role of cycles $5 \div 7$ (Dalton minimum) from the reconstructed series. The growth of the Gleisberg cycle period [3] with an increase in the proportion of reliable data illustrates this well.

An earlier paper by the author [4] has provided a detailed analysis of the $\mathrm{W}$ series (from 1749 to 2005); a 150-year harmonic specific for the certain part of the series has been distinguished there. Comparison of spectral components and the analysis of their smoothness has demonstrated essential differences in their behaviour for Wrest and Wtool (discordant characteristics of the series). Statistic characteristics of $1 \div 9$ and $10 \div 23$ cycle groups, which correspond to the reestablished and certain series, also differ. With that, the rate of distortion grows while receding into the past, and characteristics of a time domain adjacent to 1849 , which is the $8 \div 9$ cycles domain, are less distorted.

One may get some overview of the 8 and 9 cycles "quality" by estimating the correlation relationship between the growth twig Tm and the cycle maximum Wm for two variants of sample comparison: $(1 \div 9) \&(10 \div 23) ;(1 \div 7) \&(8 \div 23)$. For small samples and without the normal distribution of study values, the Shirahate criterion is deemed to be more effective. In the first instance, with a confidence figure of $\alpha=0.95$, the correlation between $\mathrm{Tm}$ and $\mathrm{Wm}$ for both cycle groups is recognised as negative. In the second instance, for $1 \div 7$ cycles, this relationship actually disappears, whereas for $8 \div 23$ cycles it remains but subsides. Hence, 8 and 9 cycles improve the quality of the Wrest series and disimprove it for Wtool one. Additionally, cycles 1, 5 and 7 have abnormally long growth branches - more than half of the cycle. Moreover, the series' interval estimations have demonstrated the inconsistency of parameters of the Wrest series [5].

In this paper, the variants of the group correction of the average values of cycles $1 \div 9$ are presented. Since local data inconsistencies play a smaller role when comparing extended fragments, relying on integral estimates of these fragments (without detailing their "complex" formation history), we obtain more weighted interval estimates. The parameters of intervals (groups of cycles) of a reliable series serve as the basis for correction. 


\section{The series' interval estimations via cycle groups}

It is common-sensical to compare groups with the same number of cycles. In this case, nine re-established cycles $1 \div 9$ (the G0 group) can be compared with six other groups: $10 \div 18,11 \div 19,12 \div 20,13 \div 21,14 \div 22,15 \div 23(\mathrm{G} 1 \div \mathrm{G} 6)$, each of nine cycles from the certain part of the series. The integrated duration of cycles $\Sigma \mathrm{Tc}$ and area of those $\Sigma \mathrm{Sq}$ in the group are matching each group; $\mathrm{w}=\Sigma \mathrm{Sq} / \Sigma \mathrm{Tc}$ shall be taken as the estimated mean value of $\mathrm{W}$ in the group. For the group of re-established cycles $\mathrm{G} 0$, these parameters equal to $1209\left(=\Sigma \mathrm{T}_{0}\right.$, months), $56713.65\left(=\Sigma \mathrm{Sq}_{0}\right), 46.91\left(\sim \mathrm{W}_{0}\right)$. The classification of cycles with respect to their duration ("long" cycles with Tc $>133$ months and "short" ones with Tc $<133$ months) allowed for parametrisation and approximation of characteristics of certain cycles groups [5]. While projecting the "rules" obtained for G1 $\div$ G6 groups onto the G0 one, the discordance between the duration and the "energetics" of the re-established series has been determined, and the necessity for the correction of the time structure of the Wrest series firstly (e.g., the relation between the "long" $\left(\mathrm{N}_{\mathrm{L}}\right)$ and "short" cycles) has been pointed out. $\mathrm{N}_{\mathrm{L}}=3(\Sigma \mathrm{Tc}=1159.0$ months, which is the mean value over the $\mathrm{G} 1 \div \mathrm{G} 6$ groups) and $\mathrm{N}_{\mathrm{L}}=2$ correspond to more realistic scenario. One shall rely upon the relation of $\mathrm{W}=\Sigma \mathrm{Sq} / \Sigma \mathrm{Tc}$ to the number of "long" cycles in the group $\mathrm{N}_{\mathrm{L}}$ (Fig. 1), where the relationship between $\Sigma \mathrm{Tc}\left(\mathrm{N}_{\mathrm{L}}\right), \Sigma \mathrm{Sq}\left(\mathrm{N}_{\mathrm{L}}\right)$ and $\mathrm{N}_{\mathrm{L}}$ for groups of 9 certain cycles each were taken from the paper [5]. This relationship shall be used for the correction of mean values of cycles of the G0 group.

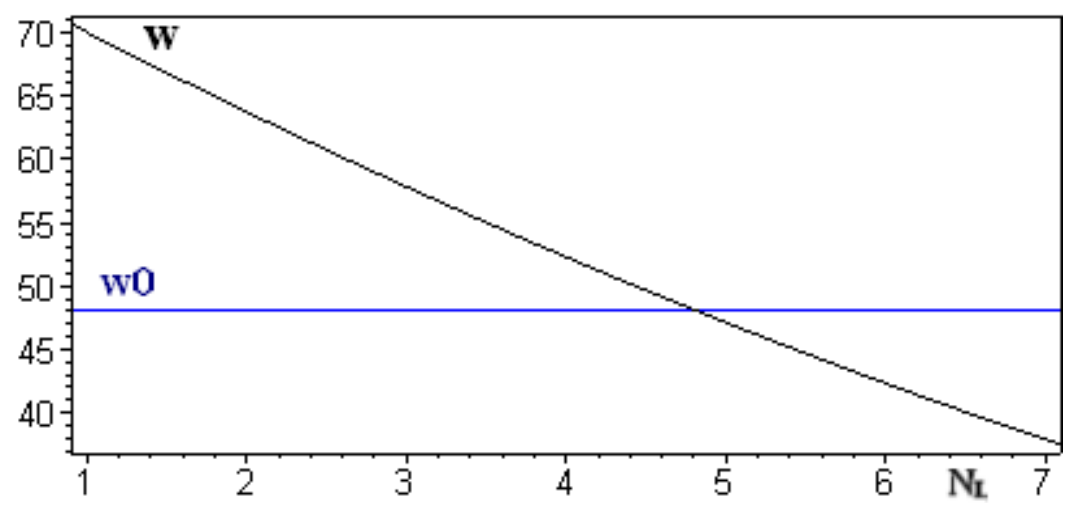

Fig. 1. The relation of the cycle mean value in the group to the number of "long" cycles $\mathrm{N}_{\mathrm{L}}$ in the group.

\section{Correction of mean values of re-established cycles}

As is obvious, the area with $\mathrm{w}>\mathrm{w}_{0}$ corresponds to $\mathrm{N}_{\mathrm{L}} \leq 4$ values. The manifestation of the increased $\mathrm{w}$ value of the re-established cycles group shall be evaluated in parameters of individual cycles. The area of the most of cycles of the G0 group is greater than (or about) the mean value of 6301.52, and it is common-sensical to assign the increment of $\left(\Sigma \mathrm{Sq}-\Sigma \mathrm{Sq}_{0}\right)$ to the Dalton Minimum (which means to associate the increment with the Dalton Minimum correction). The tabulated mean values of cycles of the re-established series are presented in Fig. 2; for illustrative purposes, the average of mean values ( 26.48) of cycles $5 \div 7$ is shown with a solid line. By associating the increased "energetics" 
of all nine cycles with these three problematic cycles, one shall obtain the increment of the $(\mathrm{w}-\mathrm{w} 0) \times 9 / 3$ mean value for each of them. The resulting mean levels for corrected mean values of cycles $5 \div 7$ are marked with dashed lines. The level 59.15 corresponds to the $\mathrm{N}_{\mathrm{L}}=3$ variant, which is the "weighed estimation of the G0 group length" (in fact, it invalidates the Dalton Minimum), and the formation of the maximum at the 77.15 level is possible for the $\mathrm{N}_{\mathrm{L}}=2$ variant.

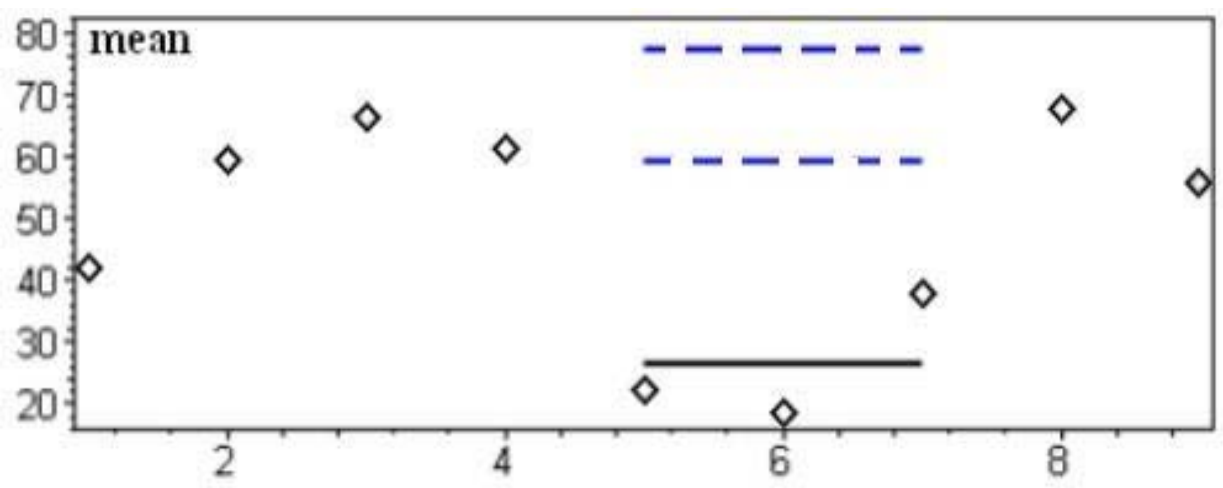

Puc. 2. Average values of cycles $1 \div 9$; axis oX - cycle number.

\section{Conclusions}

When comparing extended fragments, the local data residual plays a smaller role and more balanced estimates are obtained. Classification of cycles by duration allows us to describe the relationship between the parameters of reliable cycles and to show the inconsistency of these parameters for the 1-9 cycle group. The given scenario associates the matching of parameters of the reestablished series with the correction of the Dalton Minimum, which shall affect the characteristics of the Gleissberg cycle.

In conclusion, we note that a number of authors express a critical attitude to the restored series in the works of the Solar-Terrestrial Communications, Weather and Climate Symposium (1978) [6]. An attempt to balance the temporal characteristics of the W series cycles due to the "lost" cycle was undertaken in [7].

\section{References}

1. Hathaway David H. The Solar Cycle / https://arxiv.org/pdf/1502.07020.pdf, 2015.

2. Gleissberg $W$. A long-periodic Fluctuation of the Sun-spot Numbers // Observatory, 1939, V. 62, p. 158-159.

3. Shibaev, A. Connection between period of low-frequency component Wolf's numbers (WNS) and length of Wolf's numbers series // Aerospace Research in Bulgaria, 2017, V. 29, p. 5-9.

4. Shibaev I.G. Estimation of the reconstructed part of the Wolf series and the possibility of its correction // Solar System Research, 2008, V. 42, № 1, p. 63-72.

5. Shibaev I. Old and new versions of wolf sunspot numbers: consistency of characteristics for restored and instrumental parts of series / Proceedings of 15th International Scientific Conference "Space, Ecology, Safety" SES'2019. Sofia, Bulgaria, 2019, p. 37 - 41.

6. Solar-Terrestrial Influences on Weather and Climate. Proceeding of a Symposium. The Ohio State University, Columbus, Ohio, 24-28 August 1978. Dordrecht, Holland, 1979, P. 348.

7. Usoskin I.G., K. Mursula, and G.A. Kovaltsov. The lost sunspot cycle: Reanalysis of sunspot statistics // A\&A, 2003, V. 403, № 2, p. 743-748. 